\title{
Ruminal pH pattern, fermentation characteristics and related bacteria in response to dietary live yeast (Saccharomyces cerevisiae) supplementation in beef cattle
}

\author{
Xiangfei Zhang ${ }^{1,2, a},{ }^{2}$ Xianwen Dong ${ }^{3, a}$, Metha Wanapat ${ }^{4}$, Ali Mujtaba Shah ${ }^{1}$, Xiaolin Luo $^{2}$, \\ Quanhui Peng ${ }^{1}$, Kun Kang ${ }^{1}$, Rui Hu', Jiuqiang Guan ${ }^{2}$, and Zhisheng Wang ${ }^{1, *}$
}

\footnotetext{
* Corresponding Author: Zhisheng Wang Tel: +86-028-86293764,

E-mail: wangzs@sicau.edu.cn

${ }^{1}$ Low Carbon Breeding Cattle and Safety Production-University Key Laboratory of Sichuan Province, Animal Nutrition Institute, Sichuan Agricultural University, Chengdu 611130, China

${ }^{2}$ Institute of Plateau Animals, Sichuan Academy of Grassland Science, Chengdu 611731, China

${ }^{3}$ Chongqing Academy of Animal Science, Chongqing 402460, China

${ }^{4}$ Tropical Feed Resources Research and Development Center, Department of Animal Science, Faculty of Agriculture, Khon Kaen University, Khon Kaen 40002, Thailand

a These authors contributed equally to this work.
}

ORCID

Xiangfei Zhang

https://orcid.org/0000-0002-2186-5930 Xianwen Dong

https://orcid.org/0000-0002-5489-0163

Metha Wanapat

https://orcid.org/0000-0002-7633-052X

Ali Mujtaba Shah

https://orcid.org/0000-0003-3698-6775 Xiaolin Luo

https://orcid.org/0000-0001-9007-9813

Quanhui Peng

https://orcid.org/0000-0003-1421-9145

Kun Kang

https://orcid.org/0000-0003-1110-9792

Rui Hu

https://orcid.org/0000-0002-8703-1058

Jiuqiang Guan

https://orcid.org/0000-0002-7369-6577

Zhisheng Wang

https://orcid.org/0000-0002-2520-1912

Submitted Apr 28, 2021; Revised Jun 1, 2021 Accepted Jul 21, 2021
Objective: In this study we aimed to evaluate the effect of dietary live yeast supplementation on ruminal $\mathrm{pH}$ pattern, fermentation characteristics and associated bacteria in beef cattle. Methods: This work comprised of in vitro and in vivo experiments. In vitro fermentation was conducted by incubating $0 \%, 0.05 \%, 0.075 \%, 0.1 \%, 0.125 \%$, and $0.15 \%$ active dried yeast (Saccharomyces cerevisiae, ADY) with total mixed ration substrate to determine its dose effect. According to in vitro results, $0.1 \%$ ADY inclusion level was assigned in in vivo study for continuously monitoring ruminal fermentation characteristics and microbes. Six ruminally cannulated steers were randomly assigned to 2 treatments (Control and ADY supplementation) as two-period crossover design (30-day). Blood samples were harvested before-feeding and rumen fluid was sampled at $0,3,6,9$, and $12 \mathrm{~h}$ post-feeding on $30 \mathrm{~d}$.

Results: After $24 \mathrm{~h}$ in vitro fermentation, $\mathrm{pH}$ and gas production were increased at $0.1 \%$ $\mathrm{ADY}$ where ammonia nitrogen and microbial crude protein also displayed lowest and peak values, respectively. Acetate, butyrate and total volatile fatty acids concentrations heightened with increasing ADY doses and plateaued at high levels, while acetate to propionate ratio was decreased accordingly. In in vivo study, ruminal $\mathrm{pH}$ was increased with ADY supplementation that also elevated acetate and propionate. Conversely, ADY reduced lactate level by dampening Streptococcus bovis and inducing greater Selenomonas ruminantium and Megasphaera elsdenii populations involved in lactate utilization. The serum urea nitrogen decreased, whereas glucose, albumin and total protein concentrations were increased with ADY supplementation.

Conclusion: The results demonstrated dietary ADY improved ruminal fermentation dosedependently. The ruminal lactate reduction through modification of lactate metabolic bacteria could be an important reason for rumen $\mathrm{pH}$ stabilization induced by ADY. ADY supplementation offered a complementary probiotics strategy in improving gluconeogenesis and nitrogen metabolism of beef cattle, potentially resulted from optimized rumen $\mathrm{pH}$ and fermentation.

Keywords: Beef Cattle; pH; Rumen Fermentation; Rumen Microorganism; Saccharomyces Cerevisiae; Serum

\section{INTRODUCTION}

In recent decades, the rumen ecosystem of polygastric herbivores has been widely studied because of its critical role in feed efficiency, production and health. With the purpose of optimizing rumen environment, there were many attempts to develop new feeding strategies and the use of additives [1]. Probiotics, being defined as viable microorganisms, have a beneficial effect on animal health and have become one of the safe feeding additives following the restricted use of antibiotics. As a classified probiotic, yeast (Saccharomyces 
cerevisiae [S. cerevisiae]) can be formulated in ruminant rations on account of its advantage on improving productive performance [2]. Currently, commercial yeast products generally consist of yeast cultures, cellular extract or constituent and active dried yeast (ADY) which is otherwise known as live yeast cells [3]. Besides these products include cell components containing organics, minerals, amino acids, vitamins and yeast polysaccharides which are verified to be a superior nutritional source for autochthonous bacteria [4]. The live yeast cells can remain metabolically active in the ruminal ecosystem as well [5].

In the intensive beef industry, high readily fermentable carbohydrates with a low proportion of roughage are proposed to meet the energy requirements of production or fattening for high-producing ruminants and have obtained positive responses [6,7]. However, one of the negative consequences of a high concentration diet is the decrease of ruminal $\mathrm{pH}$ due to rapid short-chain fatty acids (SCFA) and lactate accumulations, which are fermented from non-structural carbohydrates by microbial community in the rumen $[8,9]$. Owing to the $\mathrm{pH}$ sensitivity of bacteria, failure of ruminal $\mathrm{pH}$ stabilization can cause activity suppression in microorganisms [10], and consequently lower feed utilization efficiency. Ruminal acidosis can occur with continuously low $\mathrm{pH}$ which worsens microflora disturbance and lesions in the gastrointestinal barrier [11]. Penner [12] summarized some evidence supporting the $\mathrm{pH}$ stabilizing effect of SCFA absorption. Oppositely, the decrease of ruminal $\mathrm{pH}$ was characterized by an accumulation of lactate concentration in the report of Luo et al [13]. Fortunately, in addition to benefits to production, S. cerevisiae was also proved to stabilize rumen $\mathrm{pH}$ and dry matter (DM) digestibility by Cagle et al [14], indicating a better microbial fermentation. But researches focusing on continuous monitoring and comparison between rumen volatile fatty acids (VFA) and lactic acid metabolism in the presence of live yeast, and alteration of lactate producing and consuming bacteria (Streptococcus bovis, Lactobacillus spp. and Selenomonas ruminantium, Megasphaera elsdenii) remain scarce. It rises the query of the pathway involved in stabilizing ruminal $\mathrm{pH}$ by live yeast supplementation. Whether it results from influencing metabolism of VFA or lactate through its interaction with related microbial community has also not been well established.

The studies on live S. cerevisiae supplementation in ruminant rations have shown increases in feed intake, feed efficiency, milk production enhancement and alleviating stress in lactating dairy cows $[2,15]$. But limited researches were conducted using beef cattle, particularly with respect to blood metabolic profile which can benefit from improved ruminal functions and indicates the process of metabolism and production. Beyond that, reports on impact of live yeast cells on rumen fermentation and microbes exhibited diver- gent results. No shift of rumen fermentation and bacterial population was illustrated by Magrin et al [16], on the contrary, Sousa et al [17] demonstrated different data implying ruminal fermentation improvement, stimulation of cellulytic microbes as well as $\mathrm{pH}$ stabilization. There is no consensus whether the discrepancy is derived from dose-dependent effect of yeast or not, and few researchers have focused on the question how active $S$. cerevisiae influence on ruminal VFA and lactic acid metabolism dynamically to maintain $\mathrm{pH}$ via its interaction with microbes. Therefore, our study aimed to explore the impact of ADY supplementation on ruminal $\mathrm{pH}$ pattern, fermentation characteristics, bacteria related to lactate metabolism and blood components in beef cattle.

\section{MATERIALS AND METHODS}

\section{In vitro experiment}

Experimental design and diets: This research was reviewed and approved by the Institutional Animal Care and Use Committee of Sichuan Agricultural University (YYS19021), and all procedures followed Animal Experimentation guidelines. In vitro fermentation study was carried out to evaluate the effect of gradient dietary ADY levels (S. cerevisiae, Angel Yeast Co., Ltd, Hubei, China, containing $2.0 \times 10^{10}$ cells/g) on rumen microbial fermentation characteristics. Fermentation ration was dosed at six dietary ADY levels ( $0 \%, 0.05 \%, 0.075 \%$, $0.1 \%, 0.125 \%$, and $0.15 \%$ of substrate $\mathrm{DM}$, respectively). The diet fed to ruminally fistulated beef cattle $(461.32 \pm 18.94 \mathrm{~kg})$ and in vitro fermentation substrates were consistent and formulated according to the Feeding Standard of Beef Cattle in China (2004), and concentration-to-roughage ratio was 63:37 (Table 1).

Three healthy ruminally cannulated Xuanhan Yellow cattle were used as donors of rumen fluid. After collection of rumen fluid, it was filtered through four layers of gauze and composited into flask which was placed in $39^{\circ} \mathrm{C}$ water-bath with sustained $\mathrm{CO}_{2}$ flushing. Artificial saliva was prepared referring to Menke et al [18]. The fermentation medium consisted of rumen fluid and artificial saliva in proportion of 1:2. Culture glass syringes containing $200 \mathrm{mg}$ DM fermentation substrate with different ADY dosages were used for incubation. The mixed medium in volume of $30 \mathrm{~mL}$ was transferred into the glass syringes anaerobically with rubber hose at the top for seal. There were six units per treatment incubated at $39^{\circ} \mathrm{C}$ for $24 \mathrm{~h}$ with same shaking speed $(\mathrm{n}=6)$.

Sampling and analysis: Cumulative gas production (GP) was recorded and corrected by blank control after in vitro incubation for $24 \mathrm{~h}$. Aliquot in vitro incubation fluid of each unit was filtered and collected into $10 \mathrm{~mL}$ tubes at the end of fermentation, and $\mathrm{pH}$ value was immediately determined with pH meter (pHS-3D, Rex, Shanghai, China). All samples 
Table 1. The composition and nutrient contents of diet (air-dry basis)

\begin{tabular}{lc}
\hline Items & Proportion \\
\hline Ingredient composition (\%) & \\
Corn & 27.53 \\
Wheat bran & 12.13 \\
Distilled grain & 21.52 \\
Alfalfa meal & 17.48 \\
Rice straw & 19.56 \\
NaCl & 0.50 \\
NaHCO & 0.58 \\
Premix & 0.70 \\
Total & 100.0 \\
Nutrient composition & \\
DM (\%) & 91.27 \\
CP (\%) & 11.56 \\
NEmf (MJ/kg) & 6.24 \\
NDF (\%) & 39.35 \\
ADF (\%) & 24.92 \\
EE (\%) & 2.43 \\
Ash (\%) & 7.17 \\
Ca (\%) & 0.43 \\
P (\%) & 0.31 \\
\hline DM &
\end{tabular}

DM, dry matter; $C P$, crude protein; NEmf, combined net energy; NDF, neutral detergent fiber; ADF, acid detergent fiber; $\mathrm{EE}$, ether extract.

1) Premix provided the following for per $\mathrm{kg}$ of $\operatorname{diet}$ : Vit $A, 2,200 \mathrm{IU}$; Vit $D$, 2,751 IU; Vit E, 11 IU; Cu, 10 mg; Fe, 50 mg; Zn, 30 mg; Mn, 20 mg; I, 0.5 $\mathrm{mg}$; Se, $0.1 \mathrm{mg} ; \mathrm{Co}, 0.1 \mathrm{mg}$

were then stored at $-20^{\circ} \mathrm{C}$ for further analysis. $\mathrm{NH}_{3}-\mathrm{N}$ in the fermentation medium was detected according to the method from Searle [19]. Microbial crude protein (MCP) concentration was determined with a commercial reagent kit (BCA Protein Assay Kit (CAT\#:80815-500), Tiandz Inc., Beijing, China) following manufacturer instruction. The VFA (including acetate, propionate, and butyrate) were measured via gas chromatograph (CP-3800GC, Varian, Walnut Creek, CA, USA). Fermentation fluid sample in volume of $1 \mathrm{~mL}$ was mixed with $0.2 \mathrm{~mL}$ metaphosphoric acid and centrifuged at $10,000 \mathrm{r} / \mathrm{min}$ for $15 \mathrm{~min}$ for VFA analysis. A flame ionization detector was used with an oven temperature of $200^{\circ} \mathrm{C}$. The polyethylene glycol column was operated with highly purified $\mathrm{N}_{2}$, as the carrier gas, at $8 \mathrm{~mL} / \mathrm{min}$.

\section{In vivo experiment}

Experimental design and diets: On the basis of in vitro results, effect of ADY (S. cerevisiae) on ruminal fermentation, microbes and serum metabolites of beef cattle were investigated under in vivo condition. This trial was designed according to the two-period crossover design $(n=6)$. It involved two periods, and each one consisted of $15 \mathrm{~d}$ for washout period to eliminate carryover impact and $30 \mathrm{~d}$ for treatment period. Six adult healthy Xuanhan steers $(461.32 \pm 18.94 \mathrm{~kg})$ with permanent rumen fistula were divided into two groups randomly and received either basal diet without yeast (CON) or with $0.1 \%$ ADY supplementation of total mixed ration DM (ADY). All animals were fed with basal diet (Table 1) twice daily (08:00 and 20:00) in which the ADY was mixed into ration uniformly for ADY group. Daily fed amount of each cattle was determined by feed refusal of the previous day to achieve less than $10 \%$ refusal, and water was available in barn for ad libitum.

\section{Sampling and analysis:}

i) In vivo rumen fermentation. Rumen content from each steer was collected at $0,3,6,9$, and $12 \mathrm{~h}$ after morning feeding through the ruminal cannula on the last day of in vivo treatment period $(30 \mathrm{~d})$ and filtered by four layers of gauze. $\mathrm{pH}$ was measured immediately. Samples were then stored at $-20^{\circ} \mathrm{C}$ for analysis of VFA concentration using the same instrument described above. Ruminal lactate was detected by a commercial kit purchased from Nanjing Jiancheng Biochemical Reagent Co., (Nanjing, China). Another aliquot of rumen fluid was transferred into $-80^{\circ} \mathrm{C}$ for microbial population analysis.

ii) DNA extraction, PCR primers and real-time polymerase chain reaction (PCR). The ruminal liquid was subjected to bacterial DNA extraction using Bacteria Genomic DNA Extraction Kit (Takara, Dalian, China). Quality of extracted DNA was determined using spectrophotometer (Beckman Coulter Inc., Fullerton, CA, USA) and samples with ratio of OD 260/280 nm above 1.7 were selected for later reaction. The stock DNA was then stored at $-20^{\circ} \mathrm{C}$ in aliquots. The specific PCR primers were synthesized by Huada Gene (Shenzhen, China) and used in this study for amplification of general bacteria, S. bovis, S. ruminantium, M. elsdenii and Lactobacillus spp., respectively (Table 2). Real-time PCR assays for enumeration of lactate metabolic bacterial species were performed in triplicate on 96-well plate with BIORAD Real-Time PCR detection system (Bio-Rad, Hercules, CA, USA) using SYBR Premix Ex Taq (Takara, China). All PCR reaction mixtures contained forward primer $0.4 \mu \mathrm{L}$, reverse primer $0.4 \mu \mathrm{L}$, SYBR Premix $5 \mu \mathrm{L}$, DNA template $0.8 \mu \mathrm{L}$ and DEPC- $\mathrm{H}_{2} \mathrm{O} 3.4 \mu \mathrm{L}$. The values of cycle threshold (Ct) after real-time PCR were utilized to quantify different microbial populations. The relative proportions of these microbes were expressed as a ratio to total rumen bacterial $16 \mathrm{~S}$ rDNA according to the equation: relative quantification $(\%)=2^{-(\mathrm{Ct} \text { Target }-\mathrm{Ct} \text { Total bacterial })} \times 100$, where each DNA template of our samples reacting with general bacterial primers was recorded and calculated as $\mathrm{Ct}$ (total bacterial). A negative control without the template DNA was performed in every real-time PCR assay for each primer. The PCR amplification of the target DNA, including the annealing and extension temperature, was conducted and adjusted following the references in Table 2.

iii) Blood biochemical profile. At the end of each period (30 d), blood samples from all cattle were collected by jugular 
Table 2. Specific bacterial primers sequences used for real-time polymerase chain reaction

\begin{tabular}{|c|c|c|c|c|}
\hline Target bacterial & Primer sequences $\left(5 \text { to } 3^{\prime}\right)^{1)}$ & Primer efficiency $(\%)^{2)}$ & $\operatorname{Tm}\left({ }^{\circ} \mathrm{C}\right)$ & Reference \\
\hline \multirow[t]{2}{*}{ Total bacterial } & F: CGGCAACGAGCGCAACCC & 97.2 & 55.3 & Denman and McSweeney [54] \\
\hline & R: CCATTGTAGCACGTGTGTAGCC & & & \\
\hline & R: ATGATGGCAACTAACAATAGGGGT & & & \\
\hline \multirow[t]{2}{*}{ Selenomonas ruminantium } & F: TGCTAATACCGAATGTTG & 94.5 & 63.4 & Bekele et al [56] \\
\hline & R: TCCTGCACAAGAAAGA & & & \\
\hline \multirow[t]{2}{*}{ Lactobacillus spp. } & F: GAGGCAGCAGTAGGGAATCTTC & 101.4 & 57.7 & Qi et al [58] \\
\hline & R: CAACAGTTACTCTGACACCCGTTCTTC & & & \\
\hline
\end{tabular}

${ }^{1)}$ F, forward; R, reverse.

2) Primer efficiency was calculated referring to Vitti et al [59].

vein puncture before the morning feeding. Serum was obtained by centrifugation ( $10 \mathrm{~min}, 1,000 \times \mathrm{g})$ and stored at $-20^{\circ} \mathrm{C}$ for further analyses. Concentrations of glucose, triglycerides (TG), total protein (TP), blood urea nitrogen (BUN), albumin and globulin were measured by using the automatic biochemical analyzer (Hitachi, Tokyo, Japan). The non-esterified fatty acid (NEFA) assay kit was purchased from Nanjing Jiancheng Biochemical Reagent Co. (Nanjing, China) for measurement of NEFA.

\section{Statistical analyses}

Data of in vitro study was analyzed by one-way analysis of variance using SAS 9.4 software (SAS Institute, Inc. Cary, NC, USA) to determine the effect of ADY supplementation. Responses to increasing levels of ADY (linear and quadratic) were examined using orthogonal polynomial contrast. Duncan's multiple range tests were performed to test the differences among treatments, which were denoted by different letter superscripts. For the in vivo data, individual steers were regarded as an experimental unit, and to compare the difference between CON and ADY, two sample t-test (SAS PROC TTEST) was performed using SAS software on variables of in vivo experiment. Significant differences were declared at $\mathrm{p}<0.05$.

\section{RESULTS}

\section{In vitro fermentation characteristics}

Table 3 illustrates the detail of in vitro fermentation characteristics at different ADY inclusion levels. We observed a significantly greater $\mathrm{pH}$ in response to $0.1 \% \mathrm{ADY}$ addition compared to other treatments. The dynamic change of incubation $\mathrm{pH}$ is presented in Figure 1 where significant treatment effect appeared at 2, 4, 8, $16 \mathrm{~h}$. There was a significant treatment effect of dietary ADY on $24 \mathrm{~h} \mathrm{GP}(\mathrm{p}<0.01)$, and those of $0.1 \%$ and $0.125 \%$ ADY reached the greatest value among treatments. Ammonia nitrogen $\left(\mathrm{NH}_{3}-\mathrm{N}\right)$ concentration deceased till $0.1 \%$ ADY and then increased quadratically $(\mathrm{p}<$ 0.01 ), where the lowest concentrations were observed in $0.075 \%$ and $0.1 \%$ ADY groups. Meanwhile, with the increas-

Table 3. Effect of active dried yeast at different levels on in vitro fermentation characteristics for $24 \mathrm{~h}$

\begin{tabular}{|c|c|c|c|c|c|c|c|c|c|c|}
\hline \multirow{2}{*}{ Items } & \multicolumn{6}{|c|}{ Supplemental levels of ADY (\% DM) $)^{1)}$} & \multirow{2}{*}{ SEM } & \multicolumn{3}{|c|}{ p-value } \\
\hline & 0 & 0.05 & 0.075 & 0.1 & 0.125 & 0.15 & & Treatment & Linear & Quadratic \\
\hline $\mathrm{pH}$ & $6.57^{b}$ & $6.58^{\mathrm{b}}$ & $6.60^{\mathrm{b}}$ & $6.65^{\mathrm{a}}$ & $6.58^{\mathrm{b}}$ & $6.58^{\mathrm{b}}$ & 0.01 & 0.05 & 0.34 & 0.27 \\
\hline $\mathrm{NH}_{3}-\mathrm{N}(\mathrm{mg} / \mathrm{L})$ & $170.5^{c}$ & $171.9^{b}$ & $167.8^{d}$ & $166.8^{d}$ & $169.5^{\mathrm{c}}$ & $176.2^{\mathrm{a}}$ & 0.55 & $<0.01$ & 0.12 & $<0.01$ \\
\hline MCP (mg/100 mL) & $16.8^{c}$ & $18.3^{\mathrm{b}}$ & $18.0^{\mathrm{b}}$ & $19.1^{\mathrm{a}}$ & $15.1^{d}$ & $18.4^{\mathrm{b}}$ & 0.24 & $<0.01$ & 0.86 & 0.31 \\
\hline \multicolumn{11}{|l|}{ VFA } \\
\hline Butyrate $(\mathrm{mmol} / \mathrm{L})$ & $5.91^{\mathrm{b}}$ & $6.33^{\mathrm{b}}$ & $6.11^{\mathrm{b}}$ & $7.38^{\mathrm{a}}$ & $7.36^{\mathrm{a}}$ & $7.35^{\mathrm{a}}$ & 0.14 & $<0.01$ & $<0.01$ & $<0.01$ \\
\hline Acetate: propionate & $3.42^{b}$ & $3.94^{\mathrm{a}}$ & $3.69^{a}$ & $3.17^{\mathrm{bc}}$ & $3.03^{c}$ & $2.93^{c}$ & 0.07 & $<0.01$ & $<0.01$ & $<0.01$ \\
\hline Total VFA (mmol/L) & $71.5^{d}$ & $70.7^{\mathrm{cd}}$ & $72.6^{c}$ & $77.4^{\mathrm{b}}$ & $79.0^{\mathrm{a}}$ & $78.4^{\mathrm{ab}}$ & 0.60 & $<0.01$ & $<0.01$ & $<0.01$ \\
\hline
\end{tabular}

ADY, active dried yeast (Saccharomyces cerevisiae); DM, dry matter; SEM, standard error of the mean; $\mathrm{NH}_{3}-\mathrm{N}$, ammonia nitrogen; MCP, microbial crude protein; VFA, volatile fatty acids.

1) In vitro fermentation substrates were total mixed ration with $0 \%, 0.05 \%, 0.75 \%, 0.1 \%, 0.125 \%, 0.15 \%$ ADY of substrate DM.

${ }^{a-d}$ Values in a same row with different superscripts differ significantly $(p<0.05)$ 


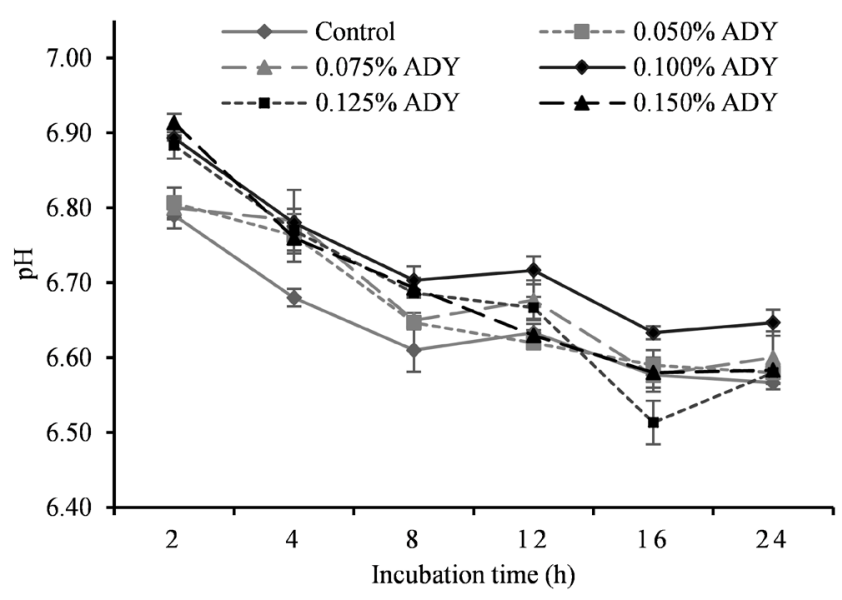

Figure 1. Effect of active dried yeast at different levels on $\mathrm{pH}$ of in vitro ruminal fermentation. Control, no yeast supplementation; ADY, active dried yeast (Saccharomyces cerevisiae) supplementation. 200 mg total mixed ration with $0 \%, 0.05 \%, 0.75 \%, 0.1 \%, 0.125 \%, 0.15 \%$ ADY of substrate dry matter were fermented in vitro for $24 \mathrm{~h}$. Error bars represent standard error.

ing of ADY supplementation, MCP in fermentation medium at $24 \mathrm{~h}$ incubation was increased and then decreased at high levels $(\mathrm{p}<0.01)$, and when $0.1 \%$ ADY was added, the highest MCP concentration was observed among the treatments. For individual VFA, acetate undulated along with increasing ADY levels $(\mathrm{p}<0.01)$ which also caused linear and quadratic enhancement of butyrate concentration $(\mathrm{p}<0.01)$. Peak levels both appeared at $0.1 \%, 0.125 \%$, and $0.15 \%$ ADY levels with no significant difference among them, and that of control exhibited the lowest point. A significant propionate improvement by increasing ADY supplementation $(\mathrm{p}<0.01)$ resulted in linear and quadratic reductions in acetate-to-propionate ratio $(\mathrm{p}<0.01)$. The ratio dropped to the bottom at dosages of $0.1 \%, 0.125 \%$, and $0.15 \%$ ADY. Total VFA in incubation medium was increased significantly with ADY supplementation levels $(\mathrm{p}<0.01)$.

\section{In vivo ruminal fermentation and microbes}

In vivo ruminal fermentation characteristics: Being consistent with in vitro fermentation $\mathrm{pH}$, in vivo ruminal $\mathrm{pH}$ reduced with time after feeding and reached the lowest point at $12 \mathrm{~h}$ in a range from 6.05 to 6.73 (Figure 2). ADY supplementation increased the ruminal $\mathrm{pH}$, and significant differences $(\mathrm{p}<0.05)$ were observed at 0,9 , and $12 \mathrm{~h}$ in contrast to control diet. Furthermore, lactate concentration increased till 6 $\mathrm{h}$ post-feeding and then decreased. Cattle that received ADY had a significantly lower level of ruminal lactate since $3 \mathrm{~h}$ after feeding (reduced by $22.5 \%, 10.8 \%, 26.4 \%$, and $33.9 \%$, respectively, $\mathrm{p}<0.05$ ). In the view of VFA (Figure 3 ), acetate, propionate and butyrate accumulated along with fermentation time. The acetate concentration for ADY supplemented beef cattle was improved significantly at 3,6 , and $12 \mathrm{~h}$ postfeeding $(\mathrm{p}<0.05)$, meanwhile, propionate concentration in ADY supplemented group was also higher at $0,6,9$, and 12 $\mathrm{h}(\mathrm{p}<0.05)$. No significant impact of ADY on butyrate content was observed until $12 \mathrm{~h}$ after feeding in the present trial. In addition, with elevated propionate concentration by ADY, the acetate-to-propionate ratio became significantly lower at 9 and $12 \mathrm{~h}$ than those in the control diet $(\mathrm{p}<0.05)$.

Microbial populations: The microbial populations related to ruminal lactate metabolism in the presence of dietary ADY administration are presented in Figure 4. The populations of microbes relative to total bacteria fluctuated after feeding. They peaked at 6 or $9 \mathrm{~h}$ post-feeding and then re-
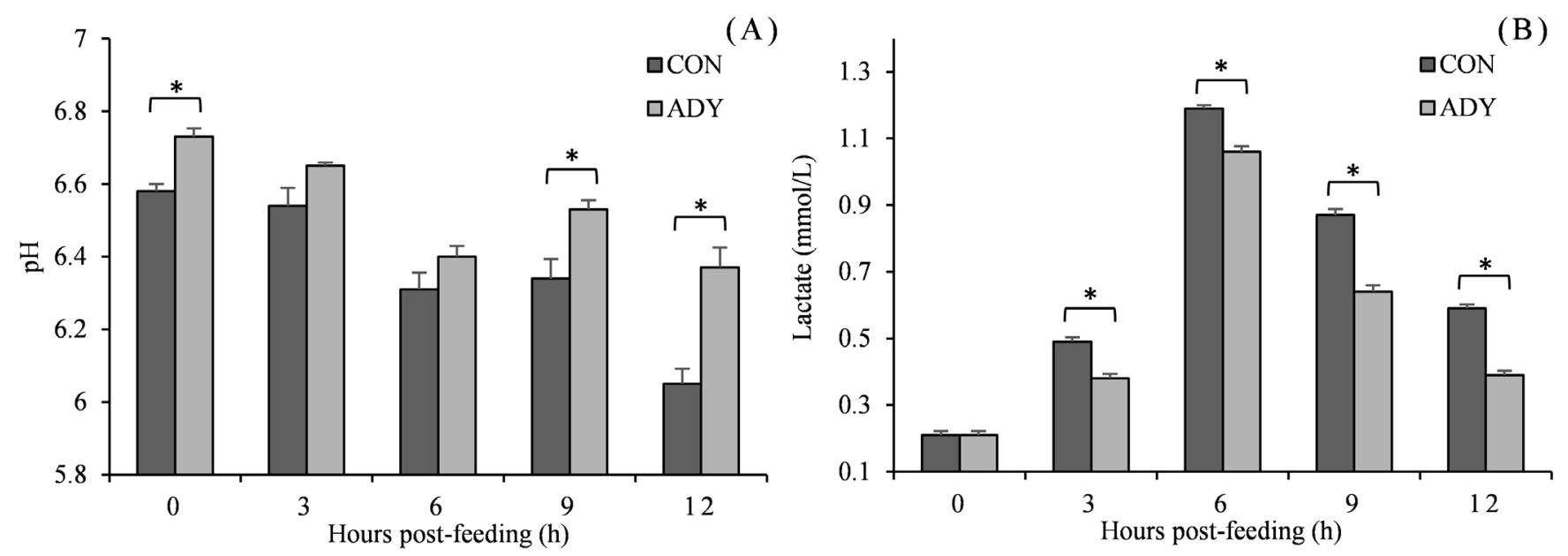

Figure 2. Influence of dietary active dried yeast supplementation on $\mathrm{pH}(\mathrm{A})$ and lactate $(\mathrm{B})$ concentrations of rumen fermentation in beef cattle. CON, control, ADY, active dried yeast (Saccharomyces cerevisiae) supplementation. Rumen contents were sampled from ruminal cannula at 0,3 , 6,9 , and $12 \mathrm{~h}$ post-feeding on $30 \mathrm{~d}$ of treatment period. Error bars represent standard error and values at the same time point with " $\star$ " differ significantly $(p<0.05)$. 

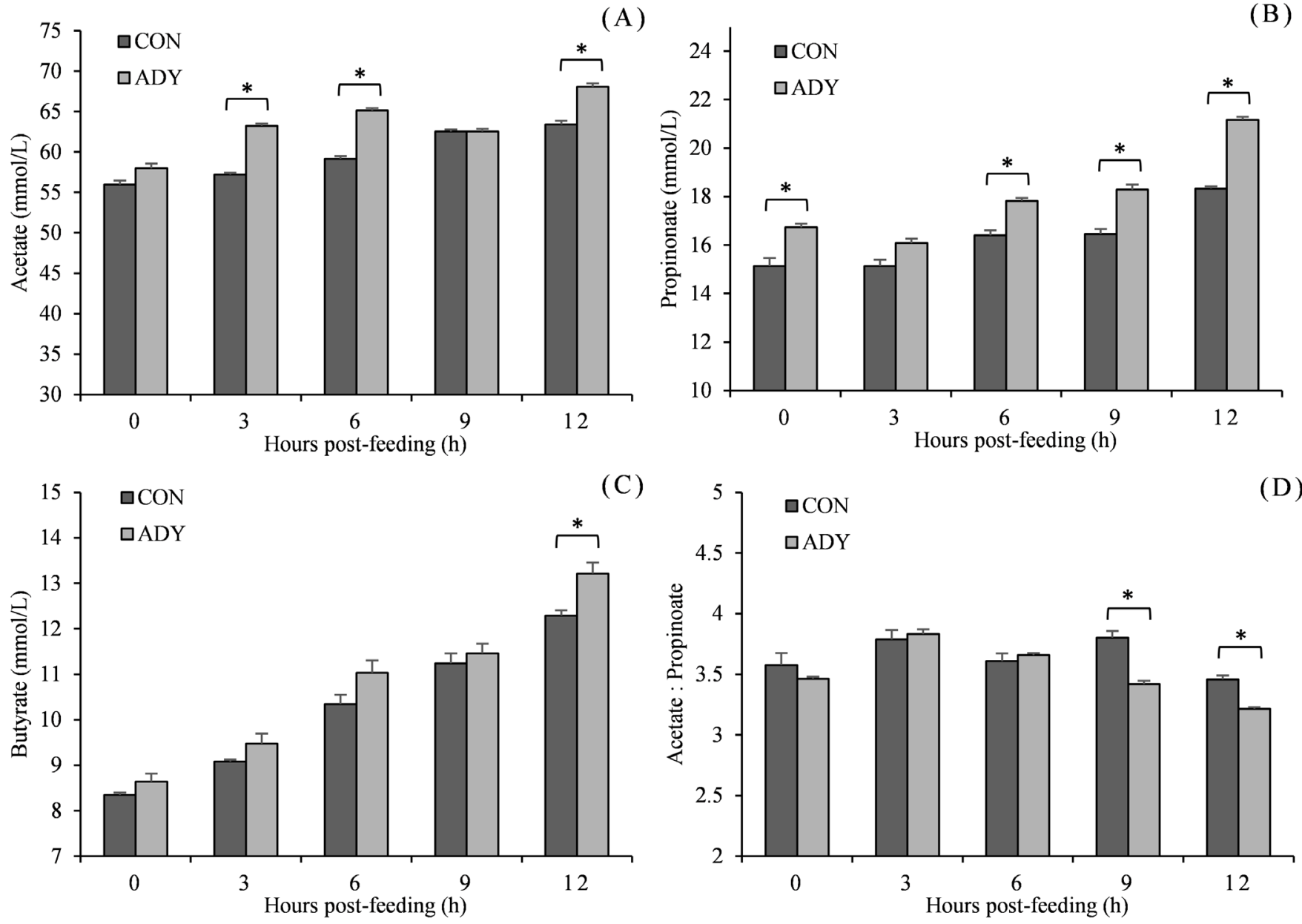

Figure 3. Influence of dietary active dried yeast supplementation on VFA concentration of rumen fermentation in beef cattle. CON, control, ADY, active dried yeast (Saccharomyces cerevisiae) supplementation. (A) Acetate, (B) propionate, (C) butyrate, (D) acetate-to-propionate ratio. Rumen contents were sampled from ruminal cannula at $0,3,6,9$, and $12 \mathrm{~h}$ post-feeding on $30 \mathrm{~d}$ of the treatment period. Error bars represent standard error and values at the same time point with "*" differ significantly $(p<0.05)$.

duced. S. bovis population (ratio to total bacterial $16 \mathrm{~S}$ rDNA) of beef cattle which received $0.1 \%$ ADY supplementation had lower population after feeding and significant difference at 3 and $6 \mathrm{~h}(\mathrm{p}<0.05)$. However, there was no difference in Lactobacillus spp. population for ADY supplementation when compared to the control diet ( $\mathrm{p}>0.05$ ) during $12 \mathrm{~h}$ post-feeding. ADY induced an increase of the relative population of $S$. ruminantium, and significant differences between ADY and control diet were witnessed at 0 and $9 \mathrm{~h}(\mathrm{p}<0.05)$. M. elsdenii population was significantly higher in ADY group at the middle and end of sampling time points $(3,6$, and $12 \mathrm{~h}$, $\mathrm{p}<0.05$ ).

\section{Serum biochemical profile}

For serum metabolites in Table 4, the results showed no significant effect on serum TG concentration between ADY and control diet. Cattle given dietary $0.1 \%$ ADY had a tendency towards higher cholesterol level $(p=0.09)$ than those given control diet, and ADY supplementation did not alter NEFA in serum. Following this, blood glucose for beef cattle consuming dietary ADY significantly increased by $21.7 \%$ on $30 \mathrm{~d}(\mathrm{p}=0.01)$. Regarding BUN, ADY supplementation exhibited significantly reduced level $(\mathrm{p}=0.01)$, and greater TP than those in the control on $30 \mathrm{~d}(\mathrm{p}=0.02)$. Albumin concentration of ADY cattle increased significantly $(\mathrm{p}=0.04)$; meanwhile, globulin also tended to be greater $(p=0.07)$. Besides the improvement of both albumin and globulin, no effect on the albumin-to-globulin ratio occurred with ADY supplementation.

\section{DISCUSSION}

With different ADY dosages, in vitro fermentation GP fluctuated and reached zenith at $0.1 \%$ and $0.125 \%$ levels. Opsi et al [20] observed an increase in fermentation GP by live yeast supplementation, however, in contrast to no effect of inactive 

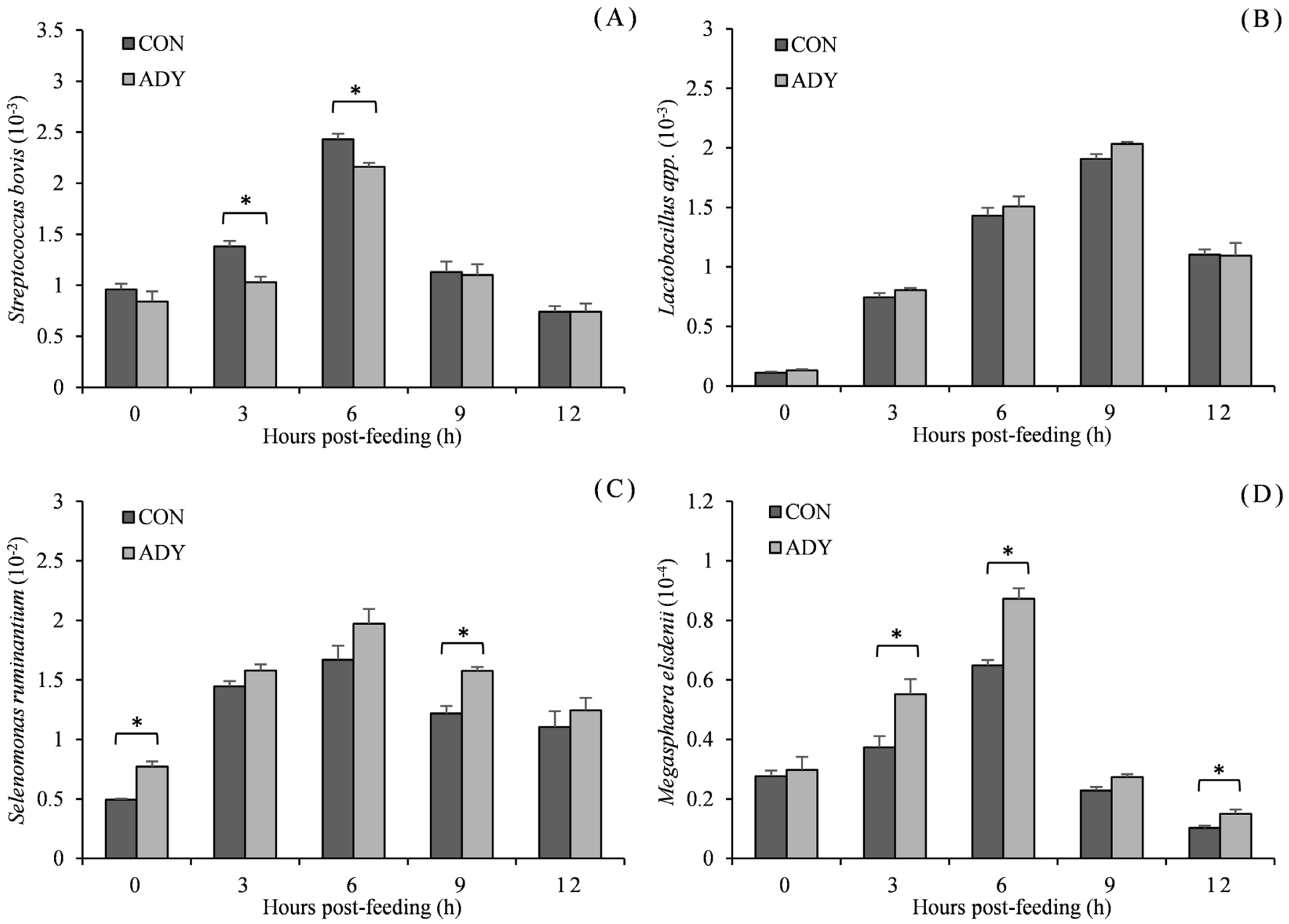

Figure 4. Effect of dietary active dried yeast supplementation on rumen microbial population of beef cattle (ratio to total bacterial 16S rDNA). (A) Streptococcus bovis, (B) Lactobacillus spp., (C) Selenomonas ruminantium, (D) Megasphaera elsdenii. CON, control, ADY, active dried yeast (Saccharomyces cerevisiae) supplementation. Rumen contents were sampled from ruminal cannula at $0,3,6,9$, and 12 h post-feeding on $30 \mathrm{~d}$ of treatment period. Error bars represent standard error and values at the same time point with " $\star$ " differ significantly $(p<0.05)$.

Table 4. Effects of dietary active dried yeast supplementation on serum metabolites ${ }^{1)}$ of beef cattle (in vivo)

\begin{tabular}{|c|c|c|c|c|}
\hline \multirow{2}{*}{ Variable } & \multicolumn{2}{|c|}{ Treatment $^{2)}$} & \multirow{2}{*}{ SEM } & \multirow{2}{*}{ p-value } \\
\hline & CON & ADY & & \\
\hline Triglycerides (mmol/L) & 0.37 & 0.38 & 0.03 & 0.89 \\
\hline Cholesterol (mmol/L) & 3.15 & 3.32 & 0.05 & 0.09 \\
\hline $\operatorname{NEFA}(\mu \mathrm{mol} / \mathrm{L})$ & 299.64 & 303.94 & 4.87 & 0.68 \\
\hline Glucose (mmol/L) & 4.05 & 4.93 & 0.21 & 0.01 \\
\hline BUN (mmol/L) & 5.00 & 3.98 & 0.24 & 0.01 \\
\hline $\mathrm{TP}(\mathrm{g} / \mathrm{L})$ & 75.13 & 86.17 & 2.83 & 0.02 \\
\hline Albumin (g/L) & 30.07 & 34.03 & 1.05 & 0.04 \\
\hline Globulin (g/L) & 45.07 & 52.13 & 2.02 & 0.07 \\
\hline$A / G$ & 0.67 & 0.66 & 0.02 & 0.79 \\
\hline
\end{tabular}

SEM, standard error of the mean; NEFA, non-esterified fatty acid; BUN, blood urea nitrogen; TP, total protein; A/G, albumin-to-globulin ratio

1) Blood samples were collected from the jugular vein before morning feeding on $30 \mathrm{~d}$ of treatment period.

${ }^{2)} \mathrm{CON}$, control; ADY, active dried yeast (Saccharomyces cerevisiae). yeast. Our results, being in good agreement with the previous investigation, provided potential evidence that live yeast addition conduces to better bacterial activity. It thereby strengthens pyruvic acid-acetate metabolic pathway in ruminal carbohydrates fermentation and produces a rise in $\mathrm{CO}_{2}$ production. A negative impact on fermentation GP of high ADY levels was also evident from this study. The reduction could be partly associated with decreased acetate and its metabolism byproducts $\mathrm{CO}_{2}$ and $\mathrm{H}_{2}$ during carbohydrate degradation [21]. On the other hand, the reason for the lower GP at $0.15 \% \mathrm{ADY}$ level may be the reduction of methane production. As reported by Tristant and Moran [22], feeding live yeast reduced methane emissions of lactating dairy cows by $4 \%$. When excess ADY supplementation was added in a transition diet, ruminal protozoa, which Methanogens lives on and within and are closely related to methane production, were suppressed [23]. Further investigation is needed to fully understand the effects of ADY 
on ruminal methanogenesis.

The in vitro $\mathrm{NH}_{3}-\mathrm{N}$ and MCP concentrations were reduced and increased around $0.1 \%$ dosage of $\mathrm{ADY}$, respectively. The finding on decreased $\mathrm{NH}_{3}-\mathrm{N}$ is in line with previous investigation on sheep of Diaz et al [24]. Thrune et al [25], however, did not find any changes in $\mathrm{NH}_{3}-\mathrm{N}$ concentration by live yeast possibly owing to relatively lower supplementation of yeast $(0.5 \mathrm{~g} / \mathrm{head} / \mathrm{d})$ in that study. The lower $\mathrm{NH}_{3}-\mathrm{N}$ concentration could be ascribed to the stimulatory effect of ADY on microbial activities and nitrogen utilization efficiency. Accordingly, MCP synthesis increased at $0.1 \%$ ADY level and contributed to greater microbial protein flow to the small intestine. Tripathi and Karim [26] demonstrated higher MCP in lambs in response to live yeast supplementation. It is suggested that bacterial growth factors, for instance, amino acid, vitamins, organic acids of live yeast cells could stimulate autochthonous microbes proliferation and growth [4]. 0.1\% ADY adding level brought about the lowest $\mathrm{NH}_{3}-\mathrm{N}$ and maximum MCP concentration. Nevertheless, an over-dose influence appeared afterward, for the possible reason that superfluous live $S$. cerevisiae cells compete for substrate utilization, and releases competitive peptides leading to reduction in bacterial activities [27].

As a vital element influencing ruminal environment and metabolism, $\mathrm{pH}$ undulates with feeding and ration structure. Abnormal ruminal $\mathrm{pH}$ that comes from ruminal acid metabolism dysfunction has been verified to negatively affect microbial structure, and cause life-threatening metabolism disorders [8]. In the present experiment, the ruminal $\mathrm{pH}$ decreased during $12 \mathrm{~h}$ of in vitro fermentation or feeding time with rapid degradation of easily degradable carbohydrate substrates into acids accumulation (VFA, lactate). Moreover, no difference at low dosages of ADY was observed in current study. When adequate dosage of ADY was added, $0.1 \%$ level resulted in noticeable improvement on ruminal $\mathrm{pH}$ to stabilize rumen environment for microorganisms. The present results were supported by the investigation of Marden et al [28] where live yeast were supplemented at 5 $\mathrm{g} / \mathrm{head} / \mathrm{d}$, and this is contrary to Geng et al [29] wherein $\mathrm{ADY}$ at $0.8 \mathrm{~g} / \mathrm{head} / \mathrm{d}$ did not change ruminal $\mathrm{pH}$ in finishing bulls. The mechanism involved in ruminal $\mathrm{pH}$ stabilization by ADY was further investigated hereinafter.

Regarding ruminal VFA, ADY supplementation elevated acetate, propionate, and butyrate concentrations significantly during in vitro fermentation study and in vivo feeding trial. The increased propionate and butyrate concentrations induced by ADY addition at $5 \mathrm{~g} / \mathrm{head} / \mathrm{d}$ in the work on lactating cows [30] coincides well with our findings. Mao et al [31] reported live yeast cells could increase ruminal bacterial population and activities, especially bacteria such as Fibrobacter succinogenes, Ruminococcus albus in in vitro fermentation. These microbes could boost carbohydrate degradation into VFA (acetate, propionate, butyrate), being mirrored by the heightened GP in this study as well. The acetate-to-propionate ratio response to live yeast displayed a significant reduction at higher levels. A similar result was also reported in Pinloche et al [30]. The increase in the level of propionate is an indispensable precursor of gluconeogenesis for ruminants, indicating the conversion to propionic acid type fermentation, feed efficiency and energy transformation improvement by ADY. As a consequence, total VFA was significantly increased and showed optimized microbial fermentation likewise. Newbold et al [32] concluded that respiration-deficient mutant of $S$. cerevisiae did not affect rumen bacteria, and conversely wild-type strain had stimulatory influence depending on oxide consumption by respiratory activity. The stimulation effect of yeast on bacterial activities could be partly linked to better anaerobic environment created by oxygen scavenging of facultative anaerobic yeast [33]. Though a slight reduction of VFA concentrations was observed at $0.125 \%$ or $0.15 \%$ ADY levels, the negative over-dose effect of ADY was not significant in the in vitro study. We speculate that, under the condition of high concentrate ration, the rapid non-structure carbohydrate degradation into VFA was improved at early phase of fermentation by ADY before its excess proliferation.

It is generally accepted that the decline of ruminal $\mathrm{pH}$ after feeding is predominantly caused by VFA and lactate production from microbial fermentation. However, some researchers claimed VFA is one of the main causes of lower ruminal $\mathrm{pH}$ [34], as ruminal lactic acid remained low in dairy cows suffering from subacute ruminal acidosis [35]. The explanation appears implausible, and it was also proposed that excess lactate accumulation owing to lactic acid metabolic dysbacteriosis plays an essential role in ruminal $\mathrm{pH}$ alteration [36]. Along with the temporary rise after feeding, ruminal lactate concentration in ADY group was lower than the control in our study, and the gap became wider with post-prandial time. From our results, besides the VFA improvement, the lower lactate concentration induced by ADY contributed to higher ruminal $\mathrm{pH}$, since the lactate $\mathrm{pKa}$ is 3.7 and has a greater contribution to $\mathrm{pH}$ reduction compared to $\mathrm{pKa} 4.7$ of SCFAs [37]. This work provides positive evidence that the $\mathrm{pH}$ stabilization property of live yeast may be the consequence of alleviated lactic acid accumulation and dissociation in rumen, which is beneficial for maintenance of rumen microbiota environment. And, further, determining how ADY stabilizes ruminal $\mathrm{pH}$ through lactate and associated bacteria was one of the objectives of the present study.

S. bovis, which has a greater relative abundance in high concentrate rations without forage [38], can ferment dietary starch into lactic acid. The acid-resistant $S$. bovis could conduce to lactate accumulation beyond the detoxifying activities of lactate utilizing bacteria. Because lactate utilizing bacteria 
may be restrained by low ruminal $\mathrm{pH}$ due to their $\mathrm{pH}$ sensitivity [39]. And while S. bovis started to multiply rapidly at early fermentation stage, yeast induced its inhibition in the current trial. Our findings are in agreement with the study by Malekkhahi et al [40], suggesting a significantly decrease in S. bovis population with live yeast supplementation. The mechanism underlying this interaction may be the competition with S. bovis for carbohydrate substrates [27]. Prevention of $S$. bovis proliferation by yeast thereby brought about lactate reduction and lower risk of ruminal acidosis. Shu et al [41] noted that cattle immunized with two lactic acid producing bacteria vaccine had markedly declined lactate concentration and higher ruminal $\mathrm{pH}$, implying the vital capability of Lactobacillus spp. and S. bovis in lactate generation [42]. In view of the above, the contribution of live yeast to another lactate producing bacteria, Lactobacillus spp., in post-prandial rumen fermentation of beef cattle was evaluated, however no significant changes was evident in our results. An experiment into repeated acidotic challenges with or without yeast by Silberberg et al [43] also showed no significant difference of Lactobacillus spp. This may be ascribed to greater ruminal $\mathrm{pH}$. Because Lactobacillus spp. which has a considerable role as a ruminal lactate producer can not only survive but be dominant at lowered $\mathrm{pH}$ (below 5.5) [44].

Furthermore, Wang et al [45] demonstrated significant proliferation in S. bovis with concomitant reductions of $S$. ruminantium and M. elsdenii populations with high-concentration diet accounted for the sudden ruminal $\mathrm{pH}$ drop. Under normal physiological conditions, lactate in rumen remains compatible with efficient ruminal environment $(<10.0 \mathrm{mmol} / \mathrm{L})$ [46], and regulated by lactolytic microbes dominated by $S$. ruminantium and $M$. elsdenii. With the aim at boosting rumen function, a study on the impact of $S$. cerevisiae on $S$. ruminantium and M. elsdenii in Holstein cows revealed an unaltered result [40]. Our data confirmed the post-prandial stimulation character of S. cerevisiae on S. ruminantium and M. elsdenii growth. Particularly, the significant differences between ADY and control diet appeared at $9 \mathrm{~h}$ post-feeding for S. ruminantium and 3 to $6 \mathrm{~h}$ for M. elsdenii when the ruminal lactate accumulated and reached relatively higher level. A positive connection was also observed in a coculture of $S$. cerevisiae and $M$. elsdenii, wherein the bacterial specific activity of lactate consumption was boosted [47]. Pinloche et al [30] reported that the higher rumen $\mathrm{pH}$ and less lactate concentration induced by live yeast, were similarly accompanied by an increase in lactate consuming bacterial genera (Megasphaera and Selenomonas). This gives good agreement with the present study. Our findings on the microbes related to lactate utilization clarified that ADY addition to ruminants is beneficial for growth of $S$. ruminantium and M. elsdenii, and more importantly, their metabolic pathway from ruminal lactate to VFA, $\mathrm{CO}_{2}$, and $\mathrm{H}_{2}$ [48].
We did not find significant influence of ADY on blood TG, cholesterol and NEFA concentrations, all of which are involved in lipid metabolism. Our results were consistent with the works by Yalcin et al [49] and Stella et al [15] showing no alteration in these energy metabolic-related indices of dairy cows and goats in response to $S$. cerevisiae supplementation. More specifically, an increasing tendency towards blood cholesterol was unveiled with live yeast addition, for the possible reason that greater VFA had a contribution to a shift in blood lipid profile [50]. The increased blood glucose by ADY supplementation is in line with a recent study in crossbred Friesian calves of Hassan et al [51]. As an indicator of utilization efficiency of carbohydrates and supplying primary energy source to body cells, glucose is principally synthesized through hepatic gluconeogenesis in ruminants. The enhanced glucose levels of cattle receiving live yeast demonstrated a better energy metabolic status. This might derive from improved rumen fermentation and greater propionate production. Additionally, from our results dietary yeast supplementation caused a significant fall in BUN concentration. It agrees with beneficial role of yeast in lowering the serum urea level in dairy cows [52]. As described by Depeters and Ferguson [53], there is a positive correlation between ruminal $\mathrm{NH}_{3}-\mathrm{N}$ and $\mathrm{BUN}$. This inference appears to be well substantiated by our previous findings on ruminal $\mathrm{NH}_{3}-\mathrm{N}$ and MCP. The decline in BUN with the addition live $S$. cerevisiae implicates a possible mechanism of improved rumen nitrogen capture ability, its conversion to microbial protein from bacterial activity and higher protein outflow from the rumen. Accordingly, an increase in the level of serum TP and albumin in beef cattle fed with $0.1 \%$ active yeast was obtained in our study. Hassan et al [51] also observed a linear effect of yeast supplementation in the ration on serum TP of calves. From these data, they had elucidated more insight on the improvement of nitrogen utilization and nutritional status for producing as supported by dietary yeast supplementation.

\section{CONCLUSION}

Active dried yeast supplementation (S. cerevisiae) in beef cattle ration boosted in vitro microbial fermentation dosedependently. When ruminal characteristics were considered collectively, the optimal response of ruminal fermentation appeared at $0.1 \%$ level of yeast addition. Moreover, our data provide further evidence that dietary live yeast favored a steady ruminal $\mathrm{pH}$ mainly relying on the decrease of lactate concentration, rather than VFAs, which is mediated by suppressing the ruminal lactate producing bacteria and stimulation towards lactate consuming bacteria. As a consequence of the optimized rumen environment and fermentation, live yeast supplementation improved the nutritional and physiological 
condition of beef cattle, including blood glucose and nitrogen metabolism.

\section{CONFLICT OF INTEREST}

We certify that there is no conflict of interest with any financial organization regarding the material discussed in the manuscript.

\section{FUNDING}

The authors gratefully acknowledge the funding support of Sichuan Science and Technology Program (2021YFYZ0001) and Angel Yeast Co., Ltd for the conduct of the research and preparation of the article.

\section{REFERENCES}

1. Hobson PN, Stewart CS. The rumen microbial ecosystem. London, UK: Blackie Academic \& Professional; 1997.

2. Moallem U, Lehrer H, Livshitz L, Zachut M, Yakoby S. The effects of live yeast supplementation to dairy cows during the hot season on production, feed efficiency, and digestibility. J Dairy Sci 2009;92:343-51. https://doi.org/10.3168/jds.20070839

3. Jiao P, He Z, Ding S, et al. Impact of strain and dose of live yeast and yeast derivatives on in vitro ruminal fermentation of a high-grain diet at two pH levels. Can J Anim Sci 2018;98: 477-87. https://doi.org/10.1139/cjas-2017-0079

4. Rossi F, Luccia AD, Vincenti D, Cocconcelli PS. Effects of peptidic fractions from Saccharomyces cerevisiae culture on growth and metabolism of the ruminal bacteria Megasphaera elsdenii. Anim Res 2004;53:177-86. https://doi.org/10.1051/ animres:2004009

5. Chaucheyras-Durand F, Walker N, Bach A. Effects of active dry yeasts on the rumen microbial ecosystem: Past, present and future. Anim Feed Sci Technol 2008;145:5-26. https:// doi.org/10.1016/j.anifeedsci.2007.04.019

6. Broderick GA. Effects of varying dietary protein and energy levels on the production of lactating dairy cows. J Dairy Sci 2003;86:1370-81. https://doi.org/10.3168/jds.S0022-0302 (03)73721-7

7. Zhang X, Zhang H, Wang Z, et al. Effects of dietary carbohydrate composition on rumen fermentation characteristics and microbial population in vitro. Ital J Anim Sci 2015;14: 3366. https://doi.org/10.4081/ijas.2015.3366

8. Plaizier JC, Krause DO, Gozho GN, McBride BW. Subacute ruminal acidosis in dairy cows: the physiological causes, incidence and consequences. Vet J 2008;176:21-31. https:// doi.org/10.1016/j.tvjl.2007.12.016

9. Wanapat M, Gunun P, Anantasook N, Kang S. Changes of rumen $\mathrm{pH}$, fermentation and microbial population as influ- enced by different ratios of roughage (rice straw) to concentrate in dairy steers. J Agric Sci 2014;152:675-85. https://doi.org/ 10.1017/S0021859613000658

10. Russell JB, Rychlik JL. Factors that alter rumen microbial ecology. Science 2001;292:1119-22. https://doi.org/10.1126/ science. 1058830

11. Nagaraja TG, Titgemeyer EC. Ruminal acidosis in beef cattle: the current microbiological and nutritional outlook. J Dairy Sci 2007;90:E17-E38. https://doi.org/10.3168/jds.2006-478

12.Penner GB. Short chain fatty acid absorption and regulation of ruminal pH. Florida Ruminant Nutrition Conference 2019; Gainesville, FL, USA: University of Florida; 2019.

13.Luo J, Ranadheera CS, King S, Evans C, Baines S. In vitro investigation of the effect of dairy propionibacteria on rumen $\mathrm{pH}$, lactic acid and volatile fatty acids. J Integr Agric 2017;16: 1566-75. https://doi.org/10.1016/S2095-3119(16)61556-3

14. Cagle CM, Tedeschi LO, Runyan CA, Callaway TR, Cravey MD. Evaluation of the effects of dried live yeast on rumen $\mathrm{pH}$ and in situ digestibility of dry matter in growing cattle. J Anim Sci 2018;96:62-3. https://doi.org/10.1093/jas/sky027. 117

15. Stella AV, Paratte R, Valnegri L, et al. Effect of administration of live Saccharomyces cerevisiae on milk production, milk composition, blood metabolites, and faecal flora in early lactating dairy goats. Small Rumin Res 2007;67:7-13. https:// doi.org/10.1016/j.smallrumres.2005.08.024

16. Magrin L, Gottardo F, Fiore E, et al. Use of a live yeast strain of Saccharomyces cerevisiae in a high-concentrate diet fed to finishing Charolais bulls: effects on growth, slaughter performance, behavior, and rumen environment. Anim Feed Sci Technol 2018;241:84-93. https://doi.org/10.1016/j. anifeedsci.2018.04.021

17.Sousa DO, Oliveira CA, Velasquez AV, et al. Live yeast supplementation improves rumen fibre degradation in cattle grazing tropical pastures throughout the year. Anim Feed Sci Technol 2018;236:149-58. https://doi.org/10.1016/j.anifeedsci.2017. 12.015

18. Menke K, Raab L, Salewski A, Steingass H, Fritz D, Schneider W. The estimation of the digestibility and metabolizable energy content of ruminant feedingstuffs from the gas production when they are incubated with rumen liquor in vitro. J Agric Sci 1979;93:217-22. https://doi.org/10.1017/S00218596000 86305

19. Searle PL. The Berthelot or indophenol reaction and its use in the analytical chemistry of nitrogen. A review. Analyst 1984;109:549-68. https://doi.org/10.1039/AN9840900549

20.Opsi F, Fortina R, Tassone S, Bodas R, LÓPez S. Effects of inactivated and live cells of Saccharomyces cerevisiae on in vitro ruminal fermentation of diets with different forage: concentrate ratio. J Agric Sci 2012;150:271-83. https://doi. org/10.1017/s0021859611000578

21. Besharati M. Effect of Saccharomyces cerevisiae supplemen- 
tation on in vitro gas production of biscuit waste. Glob J Anim Sci Res 2015;3:512-7.

22. Tristant D, Moran C. The efficacy of feeding a live probiotic yeast, Yea-Sacc, on the performance of lactating dairy cows. J Appl Anim Nutr 2015;3:e12. https://doi.org/10.1017/jan. 2015.10

23. Cagle CM, Fonseca MA, Callaway TR, Runyan CA, Cravey MD, Tedeschi LO. Evaluation of the effects of live yeast on rumen parameters and in situ digestibility of dry matter and neutral detergent fiber in beef cattle fed growing and finishing diets. Appl Anim Sci 2020;36:36-47. https://doi.org/10.15232/ aas.2019-01888

24.Diaz TG, Branco AF, Jacovaci FA, et al. Inclusion of live yeast and mannan-oligosaccharides in high grain-based diets for sheep: Ruminal parameters, inflammatory response and rumen morphology. PLoS ONE 2018;13:e0193313. https:// doi.org/10.1371/journal.pone.0193313

25.Thrune M, Bach A, Ruiz-Moreno M, Stern MD, Linn JG. Effects of Saccharomyces cerevisiae on ruminal $\mathrm{pH}$ and microbial fermentation in dairy cows: Yeast supplementation on rumen fermentation. Livest Sci 2009;124:261-5. https:// doi.org/10.1016/j.livsci.2009.02.007

26. Tripathi MK, Karim SA. Effect of individual and mixed live yeast culture feeding on growth performance, nutrient utilization and microbial crude protein synthesis in lambs. Anim Feed Sci Technol 2010;155:163-71. https://doi.org/10.1016/ j.anifeedsci.2009.11.007

27. Chaucheyras-Durand F, Masseglia S, Fonty G. Effect of the microbial feed additive Saccharomyces cerevisiae CNCM I-1077 on protein and peptide degrading activities of rumen bacteria grown in vitro. Curr Microbiol 2005;50:96-101. https://doi.org/10.1007/s00284-004-4433-1

28. Marden JP, Julien C, Monteils V, Auclair E, Moncoulon R, Bayourthe $\mathrm{C}$. How does live yeast differ from sodium bicarbonate to stabilize ruminal $\mathrm{pH}$ in high-yielding dairy cows? J Dairy Sci 2008;91:3528-35. https://doi.org/10.3168/jds.20070889

29. Geng CY, Ren LP, Zhou ZM, Chang Y, Meng QX. Comparison of active dry yeast (Saccharomyces cerevisiae) and yeast culture for growth performance, carcass traits, meat quality and blood indexes in finishing bulls. Anim Sci J 2016;87:982-8. https:// doi.org/10.1111/asj.12522

30.Pinloche E, McEwan N, Marden JP, Bayourthe C, Auclair E, Jamie Newbold C. The effects of a probiotic yeast on the bacterial diversity and population structure in the rumen of cattle. PLoS ONE 2013;8:e67824. https://doi.org/10.1371/ journal.pone.0067824

31. Mao H, Mao H, Wang JK, Liu JX, Yoon I. Effects of Saccharomyces cerevisiae fermentation product on in vitro fermentation and microbial communities of low-quality forages and mixed diets. J Anim Sci 2013;91:3291-8. https://doi.org/10.2527/ jas.2012-5851
32. Newbold CJ, Wallace R, McIntosh F. Mode of action of the yeast Saccharomyces cerevisiae as a feed additive for ruminants. Br J Nutr 1996;76:249-61. https://doi.org/10.1079/BJN 19960029

33. Oeztuerk H, Schroeder B, Beyerbach M, Breves G. Influence of living and autoclaved yeasts of Saccharomyces boulardii on in vitro ruminal microbial metabolism. J Dairy Sci 2005; 88:2594-600. https://doi.org/10.3168/jds.S0022-0302(05) 72935-0

34. Sato S. Pathophysiological evaluation of subacute ruminal acidosis (SARA) by continuous ruminal $\mathrm{pH}$ monitoring. Anim Sci J 2016;87:168-77. https://doi.org/10.1111/asj.12415

35. Krause KM, Oetzel GR. Inducing subacute ruminal acidosis in lactating dairy cows. J Dairy Sci 2005;88:3633-9. https:// doi.org/10.3168/jds.S0022-0302(05)73048-4

36.Lettat A, Nozière P, Silberberg M, Morgavi DP, Berger C, Martin C. Rumen microbial and fermentation characteristics are affected differently by bacterial probiotic supplementation during induced lactic and subacute acidosis in sheep. BMC Microbiol 2012;12:142. https://doi.org/10.1186/1471-2180$12-142$

37.Enemark JMD, Jorgensen R, Enemark PS. Rumen acidosis with special emphasis on diagnostic aspects of subclinical rumen acidosis: a review. Veterinarija ir zootechnika 2002; 20:16-29.

38. Petri RM, Forster RJ, Yang W, McKinnon JJ, McAllister TA. Characterization of rumen bacterial diversity and fermentation parameters in concentrate fed cattle with and without forage. J Appl Microbiol 2012;112:1152-62. https://doi. org/10.1111/j.1365-2672.2012.05295.x

39. Calsamiglia S, Blanch M, Ferret A, Moya D. Is subacute ruminal acidosis a $\mathrm{pH}$ related problem? Causes and tools for its control. Anim Feed Sci Technol 2012;172:42-50. https://doi.org/10.1016/j.anifeedsci.2011.12.007

40. Malekkhahi M, Tahmasbi AM, Naserian AA, et al. Effects of supplementation of active dried yeast and malate during sub-acute ruminal acidosis on rumen fermentation, microbial population, selected blood metabolites, and milk production in dairy cows. Anim Feed Sci Technol 2016;213:29-43. https://doi.org/10.1016/j.anifeedsci.2015.12.018

41.Shu Q, Gill HS, Hennessy DW, Leng RA, Bird SH, Rowe JB. Immunisation against lactic acidosis in cattle. Res Vet Sci 1999;67:65-71. https://doi.org/10.1053/rvsc.1998.0284

42. Belanche A, Doreau M, Edwards JE, Moorby JM, Pinloche E, Newbold CJ. Shifts in the rumen microbiota due to the type of carbohydrate and level of protein ingested by dairy cattle are associated with changes in rumen fermentation. J Nutr 2012;142:1684-92. https://doi.org/10.3945/jn.112.159574

43. Silberberg M, Chaucheyras-Durand F, Commun L, et al. Repeated acidosis challenges and live yeast supplementation shape rumen microbiota and fermentations and modulate inflammatory status in sheep. Animal 2013;7:1910-20. https:// 
doi.org/10.1017/S1751731113001705

44. Mickdam E, Khiaosa-ard R, Metzler-Zebeli BU, Klevenhusen F, Chizzola R, Zebeli Q. Rumen microbial abundance and fermentation profile during severe subacute ruminal acidosis and its modulation by plant derived alkaloids in vitro. Anaerobe 2016;39:4-13. https://doi.org/10.1016/j.anaerobe. 2016.02.002

45. Wang H, Pan X, Wang C, Wang M, Yu L. Effects of different dietary concentrate to forage ratio and thiamine supplementation on the rumen fermentation and ruminal bacterial community in dairy cows. Anim Prod Sci 2015;55:189-93. https://doi.org/10.1071/AN14523

46. Keunen JE, Plaizier JC, Kyriazakis L, et al. Effects of a subacute ruminal acidosis model on the diet selection of dairy cows. J Dairy Sci 2002;85:3304-13. https://doi.org/10.3168/jds. S0022-0302(02)74419-6

47. Chaucheyras F, Fonty G, Gouet P, Bertin G, Salmon J-M. Effects of a strain of Saccharomyces cerevisiae (Levucell ${ }^{\oplus}$ SC), a microbial additive for ruminants, on lactate metabolism in vitro. Can J Microbiol 1996;42:927-33. https://doi.org/10. 1139/m96-119

48. Fonty G, Chaucheyras-Durand F. Effects and modes of action of live yeasts in the rumen. Biologia 2006;61:741-50. https:// doi.org/10.2478/s11756-006-0151-4

49. Yalcin S, Yalcin S, Can P, Gürdal AO, Bagci C, Eltan O. The nutritive value of live yeast culture (Saccharomyces cerevisiae) and its effect on milk yield, milk composition and some blood parameters of dairy cows. Asian-Australas J Anim Sci 2011;24:1377-85. https://doi.org/10.5713/ajas.2011.11060

50. Kowalik B, Skomial J, Pajak JJ, et al. Population of ciliates, rumen fermentation indicators and biochemical parameters of blood serum in heifers fed diets supplemented with yeast (Saccharomyces cerevisiae) preparation. Anim Sci Pap Rep 2012;30:329-38.

51. Hassan A, Salem A, Kholif A, et al. Performance of crossbred dairy Friesian calves fed two levels of Saccharomyces cerevisiae: intake, digestion, ruminal fermentation, blood parameters and faecal pathogenic bacteria. J Agric Sci 2016;154:148898. https://doi.org/10.1017/S0021859616000599

52.Doležal P, Dvořáček J, Doležal J, et al. Effect of feeding yeast culture on ruminal fermentation and blood indicators of Holstein dairy cows. Acta Vet Brno 2011;80:139-45. https:// doi.org/10.2754/avb201180020139

53. Depeters EJ, Ferguson JD. Nonprotein nitrogen and protein distribution in the milk of cows. J Dairy Sci 1992;75:3192209. https://doi.org/10.3168/jds.S0022-0302(92)78085-0

54.Denman SE, McSweeney CS. Development of a real-time PCR assay for monitoring anaerobic fungal and cellulolytic bacterial populations within the rumen. FEMS Microbiol Ecol 2006;58:572-82. https://doi.org/10.1111/j.1574-6941. 2006.00190.x

55.Stevenson DM, Weimer PJ. Dominance of Prevotella and low abundance of classical ruminal bacterial species in the bovine rumen revealed by relative quantification real-time PCR. Appl Microbiol Biotechnol 2007;75:165-74. https:// doi.org/10.1007/s00253-006-0802-y

56. Bekele AZ, Koike S, Kobayashi Y. Genetic diversity and diet specificity of ruminal Prevotella revealed by $16 \mathrm{~S}$ rRNA genebased analysis. FEMS Microbiol Lett 2010;305:49-57. https:// doi.org/10.1111/j.1574-6968.2010.01911.x

57. Ouwerkerk D, Klieve AV, Forster RJ. Enumeration of Megasphaera elsdenii in rumen contents by real-time Taq nuclease assay. J Appl Microbiol 2002;92:753-8. https://doi.org/10.1046/ j.1365-2672.2002.01580.x

58. Qi H, Xiang Z, Han G, Yu B, Huang Z, Chen D. Effects of different dietary protein sources on cecal microflora in rats. Afr J Biotechnol 2011;10:3704-8. https://doi.org/10.5897/ AJB10.2677

59. Vitti A, La Monaca E, Sofo A, et al. Beneficial effects of Trichodermaharzianum T-22 in tomato seedlings infected by Cucumber mosaic virus (CMV). BioControl 2015;60: 135-47. https://doi.org/10.1007/s10526-014-9626-3 